\title{
DISCOURSE ANALYTICAL PERSPECTIVES OF DONALD TRUMP'S LINGUISTIC BEHAVIOUR
}

\author{
Uliana Potiatynyk \\ PhD, Associate Professor, Ivan Franko National University of Lviv, Ukraine \\ e-mail: ulianapo@gmail.com,orcid.org/0000-0001-8886-3633 \\ Tetiana Orshynska \\ PhD, Associate Professor, Ivan Franko National University of Lviv, Ukraine \\ e-mail: orshyn@gmail.com,orcid.org/0000-0002-4170-005X
}

\section{Summary}

The paper is an attempt to explore some of the most distinctive and unique characteristics that define the linguistic representation of Donald Trump's communicative behavior as it manifests itself during his 2016 presidential campaign rallies, press conferences and various TV appearances and official speeches (delivered prior to and after assuming presidency). By means of critical discourse analysis (CDA), the author tries to identify what linguistic means might contribute to making Trump appealing to his base. Since he is commonly believed to appeal to emotions in his electorate, the author examines instances where he persuades and manipulates the public by generating an emotional response in them. More specifically, the study explores such affective components of communicative behavior as repetitions, hyperbole, attaching labels and, finally, his use of implicit meaning and presuppositions. Our corpus suggests that activating the affective component is strategic for Trump, although it is also true that appeal to emotions is natural and often intuitive on his part. Repetitions and negative labeling make sure that certain ideas become permanent in the minds of prospective voters and that opponents are subconsciously associated with something negative. Hyperbole is revealed to take different forms and serve several functions in his speech. Finally, the paper discusses implicitness in Trump's language, notably existential, propositional and value assumptions, which help 'unpack' ideas embedded in his propositions.

Keywords: CDA, hyperbole, implicitness, presuppositions, "trial balloon”.

\section{DOI: https://doi.org/10.23856/4009}

\section{Introduction}

The paper examines the linguistic behavior of Donald Trump, the current US President, who won the presidency in the November 8, 2016 election. When this study was being undertaken, Trump had just succeeded in overtaking all of his GOP rivals in the primary elections and winning the Republican nomination for president. His successful run during the primaries took many by surprise as this candidate seemed - certainly to most experts, analysts and politicians on both sides of the political spectrum - to be questionably qualified to even be in the race for American presidency. In the initial stages of the campaign, there was a sense that Trump's lack of political expertise, his questionable ethics and dubious values as well as his past improprieties, erratic behavior and offensive language would quickly remove him from the presidential race. Yet his obvious incompetence did not seem to affect his popularity among a considerable segment of the US public, and as his ratings rose, political pundits and media analysts raced to account for the 'Trump phenomenon'. A number of factors were cited as having played a role 
in boosting his appeal to ordinary voters, among them being his 'outsider' status as a politician, his business acumen (as a real-estate developer, he claims to be worth billions, although he has repeatedly refused to disclose his tax returns, which would reveal how much he really owns and earns), and the fact that he is a celebrity, having hosted The Apprentice (an American game show that judges business skills of contestants) on television for over ten years. Few seem to call into question that these factors, among many others that have contributed to his ultimate political success, were at play to varying degrees over the eighteen months of the presidential race. However, what also appears reasonable to assume is that Trump's communicative behavior as an integral part of his political persona must have played an equally significant (if not greater) role in his eventual success. To try to put this assumption to a test, the present study will draw on a corpus of public utterances delivered by Trump during rallies, interviews, news conferences, television debates and even tweets - he is an avid Twitter user - to interpret first the presidential candidate's and now the president's hold on the Republican electorate over almost four years. In her analysis of Trump's verbal behavior, the author will rely on critical discourse analysis (CDA from now on) (Fairclough, 1995, 2003; van Leeuwen, 2008), which is arguably one of the most profitable methods of investigation of political and ideological discourse. CDA is a perspective geared towards analyzing how individuals and institutions use language to engender change in people's attitudes and, subsequently, in dominant social discourses. Linguistic representations are seen as particular articulations of societal discourse, which is variously interpreted as a mediation, decontextualization, or recontextualization of social practice (Fairclough and Fairclough, 2015: 38-40; van Leeuwen, 2008: 3). Researchers working within CDA lay special emphasis on "social problems, and especially the role of discourse in the production and reproduction of power abuse or domination" (van Dijk, 2001: 96). As a result, the study of text and context within CDA is necessarily socio-politically situated, which is quite essential for the present study, given that the discourse in which a politician engages is at the intersection of issues of ideology, culture, and morality among others.

\section{Language and political communication}

It will probably be safe to say that there are few social contexts in which language evaluation is more crucial than in politics. Candidates for office are sometimes judged exclusively by what they say and how they say it. Given the fact that politicians are expected to articulate primarily the ideology of their party, they may not have much leeway as to the content of their message. Therefore, it may well be that how the message is communicated will play the primary role in how the politician is perceived. This, however, may not necessarily hold true for Donald Trump, as, on the one hand, his ideas do not always accord with mainstream Republican views on many issues, and, on the other, he has never held any political office before. It will be nonetheless fair to say that Trump's rhetorical strategies are a central part of his personal and political identity and their role, therefore, should not be underestimated, in particular with respect to what impact they have on his supporters. It has been generally acknowledged that Trump as a politician is highly unusual - not to say idiosyncratic - in his communicative behavior. Some experts have even dismissed his use of language as 'word salad' (Lakoff, 2016a; Libit, 2016).

At the same time, despite Trump's fragmented sentences, syntactic and lexical repetitions, imprecision and vagueness, reliance on appeals to emotions rather than rational discourse, his message has resonance among many in the conservative electorate. His rise to power is indicative of not only the appeal of what he proposes, but also the verbal/non-verbal strategies he uses to convey it. It is thus easy to see why Lakoff believes that Trump "is simply using effective 
discourse mechanisms to communicate" what he wants to his audience (Lakoff, 2016a). It may well be that his use of language is more strategic and his discursive strategies are intentionally selected to a greater degree than many give him credit for. In the present paper, we have attempted to parse his linguistic behavior in order to determine what it is that makes it different from others' and what discursive strategies might make him so appealing to his supporters.

\section{Appeal to Pathos over Logos}

The rhetorical pattern of elevating appeal to emotions over appeal to logic (Aristotle, 2012: 7-8) is a feature that characterizes all demagogues. As all demagogues, past and present, Trump has exploited weaknesses in the democratic system, its institutions and the government, on the one hand, and legitimate anxieties and frustrations of the public, on the other. His populism, however, as became abundantly clear early on in the campaign, has been quite different from politicians in the same tradition that had come before him, most notably Wallace and McCarthy (Healy and Haberman, 2015). Unlike most of the other 20th-century demagogues, Trump has an undeniable charisma, and, according to Healy and Haberman (Healy and Haberman, 2015), he can charm and entertain his audiences with an engaging simplicity and looseness of language that may sound "almost like water-cooler talk or neighborly banter" (Healy and Haberman, 2015). Due in great measure to such charismatic ease and authenticity of language, Trump's major difference from other populists is that his political strategies have been proven to be effective as his successful presidential run amply demonstrated. Given that utilization of (negative) emotions by populists is a necessary component of their strategies (Stanley, 2008), a legitimate question arises as to what sets Trump's exploitation of affective aspects of communication apart from others'? To attempt to answer this question, let us consider some of the communicative and rhetorical patterns that generate such a notable emotional response in his electorate.

\subsection{Repetitions as an affective component of Trump's discourse}

A feature that becomes immediately apparent to anyone listening to Trump address the public is constant repetitions. These are of various kinds, most notably word-for-word repetitions of the same syntactic pattern, lexical repetitions, and repetitions whereby semantically similar ideas are reproduced through a lexically different pattern:

(1) Who would have believed that when we started this journey...that the Republican party would get 60 percent more votes than it received eight years ago. Who would have believed this. Who would have believed this (Trump, 2016).

(2) Free trade can be wonderful if you have smart people, but we have people that are stupid. We have people that aren't smart (Trump, 2015).

Trump's critics have mocked him for saying the same thing repeatedly, accusing the candidate of having nothing to say, with some suggesting a low educational level and paucity of thought. At the same time, it may be useful to consider how this particular characteristic figures in the rhetorical strategies of other demagogues in history. Kenneth Burke (Burke, 1974), in his analysis of the rhetoric of Hitler's Mein Kampf, argues that the author convincingly shows "the power of endless repetition" (Burke, 1974: 217) and the effectiveness of "the sloganizing repetitiousness of standard advertising technique" (Burke, 1974: 218) that was used in spreading the destructive Nazi ideology (Burke, 1974: 218). Now cognitive scholars are able to explain how exactly such repetitions work and what effect they have on our minds. Neuroscience has definitively proven that there are neural links which connect words that we say to the circuits in the brain that determine their meaning. When words are said and heard, it means that different 
portions of the brain are activated simultaneously through nerve impulses, or neural firing (Lakoff, 2008: 128), which enables different parts of the brain to connect and coordinate with each other. As a result, the more a word or phrase is repeated, the more the circuit is activated and the stronger it becomes. In practice, what it means is that the more people are exposed to certain language, the more susceptible they become to ideas behind it. So when Trump promises "Win, win, win. We're gonna win so much you'll get tired of winning," he is not just reiterating his message, he ensures that he, Trump, is metonymically linked to the idea of winning. Moreover, Lakoff is convinced that whenever the media repeat what Trump says, they reinforce his frames by making sure that millions of people hear them repeatedly (Lakoff, 2016 b).

\subsection{Blurring the boundaries between true and false through hyperbole}

Another feature that makes Trump quite distinct from politicians in the more traditional mold is his extensive use of hyperbole. Hyperbole is construed as excessive exaggeration, most commonly resorted to for rhetorical reasons, language play, especially humor; it is often indicative of sensationalism in reporting, particularly in tabloid press (Richardson, 2007: 65). Considering that hyperbole occupies a grey area between truth and falsehood, and given Trump's "troublesome relationship with the truth" (Nichols, 2016), hyperbolized statements quite predictably figure prominently in his discourse. Besides, according to Claridge, hyperbole, not unlike metaphor, deals not so much with the 'description' of experience as with the 'evaluation' of it, which entails that it has "an important affective component" (Claridge, 2014: 1). We believe it is primarily this emotive element that Trump exploits in his use of hyperbole.

Interestingly, Trump is quite aware of his propensity for exaggeration: he famously coined an oxymoronic term 'truthful hyperbole' in his autobiographical memoir The Art of the Deal (Trump, 2016 c), which he used to describe the blatant truth-stretching that he utilized to successfully close sales:

The final key to the way I promote is bravado. I play to people's fantasies... That's why a little hyperbole never hurts. People want to believe that something is the biggest and the greatest and the most spectacular. I call it truthful hyperbole. It's an innocent form of exaggeration and it's a very effective form of promotion. (Trump, 2016: 58).

Not surprisingly, having proved to be a helpful tool in business, hyperbole, as an affective means of persuasion, has become no less effective in Trump's self-promotion during his presidential campaign and after he was elected president. His use of hyperbole is frequent and diverse and is articulated through varied language means, among them being comparatives and superlatives, clauses in combination with superlative adjectives expressing action or quality in the extreme degree, categorical pronouns (nobody, everybody etc.), and numerical expressions:

(3) Nobody would be tougher on ISIS than Donald Trump. Nobody (Trump, 2015).

(4) I'll be the greatest jobs president that God ever created (Trump, 2015).

(5) I have made billions of billions of dollars making deals all over the world (Shamsian, 2015).

Hyperbolic intensification is found primarily at the extreme ends of the scale (the most vs. the least) (Claridge, 2014: 9) and hyperbolized statements involving extremes in Trump's discourse seem to be the most prevalent, which contributes to the perception of his persona as someone who has a tendency to boast about himself and everything associated with him.

Consistent with our initial intuitions, our data shows that Trump's hyperbolized utterances are highly selective: he uses semantically negative expressions to give hyperbolic accounts (descriptions, evaluations etc.) of his opponents, the Democrats, critics among the Republicans, President Obama etc., and positive hyperbole to refer to himself and people supporting him. The manipulative 
aspect of hyperbole especially comes to the fore when Trump talks about his predecessor, President Obama, where hyperbole can take on a particularly sinister dimension, as in this utterance:

(6) The irresponsible rhetoric of our President, who has used the pulpit of the presidency to divide us by race and color, has made America a more dangerous environment than frankly I have ever seen and anybody in this room has ever watched or seen (Trump, 2016 b).

This statement is notable not only for the hyperbole in the second part of it, but also for an instance of overstatement in the first part, which does not agree with the state of affairs: the claim is so extreme as to be factually impossible or absurd. It is worth noting that Trump has never been able to elaborate on or corroborate this allegation. It also shows that it is sometimes impossible to tell where non-literal language (hyperbole) ends and literal (untruthful statement, falsehood) begins.

Hyperbolic utterances involving numerical lexemes, such as hundreds, thousands, billions, trillions etc., which show a high frequency in Trump's speech, contribute a sense of vagueness and under-specificity to his statements. The very unverifiability of such phrasing prevents the public from recognizing Trump's inaccuracies, negligence with regard to facts and, not infrequently, incompetence. By resorting to numerical hyperbole, Trump thus safeguards his credibility, even though many of his statements are factually not true.

Furthermore, the manipulative potential of hyperbole is actualized through the use of words whose semantics "exceeds the credible limits of fact in the given context" (Claridge, 2014, p. 5). Some scholars call them degree nouns, i.e. nouns that come with an inherent evaluation of either positive or negative character and, as a result, tend to be hyperbolic (Paradis, 2011: 243) The main characteristic of degree nouns is that they do not identify entities or phenomena, but rather describe and evaluate them; they thus tend to be relational and underspecified (Paradis, 2011: 243). In our estimates, degree nouns with negative semantics appear to predominate in Trump's language. It is easy to see why Trump makes an extensive use of them - they tend to reflect the dark pessimism permeating his rhetoric:

(7) The Trans-Pacific Partnership is another disaster done and pushed by special interests who want to rape our country - just a continuing rape of our country. It's a harsh word, but it's true (Ballotpedia) ers, as in:

Degree nouns are often modified by non-gradable adjectives, which serve as reinforc-

(8) Obamacare is a complete and total disaster. It's imploding as we sit (Mangan, 2017)

This propensity to frame a situation as considerably more grim than it really is has been nowhere more manifest than in his inaugural address on January 20, 2017. In it, the newly sworn-in President paints a bleak picture of the USA as a country plagued by countless ills, i.e. devastated manufacturing, rampant crime, troubled schools, etc. He refers to all this as American carnage:

(9) This American carnage stops right here and stops right now (Trump, 2017).

Although the use of such a semantically extreme noun is hardly justified - it depicts a situation which is factually and statistically not true - one could argue that the affective component of this hyperbole overrides the obvious overstatement as it signals the speaker's high emotional engagement.

Another important function of Trump's hyperbole seems to be that by means of flagrant exaggeration, he can claim 'plausible deniability', meaning that the phrasing is so overstated, he might argue, that no one could possibly take it literally. The use of such hyperbole is clearly strategic: his formulations are so imprecise and so open to refutation that this allows him not to take responsibility for his words.

And finally, hyperbolized statements may often be made with a view to establishing a particular line for negotiation or finding out how far he can push his agenda. This is yet another 
function of Trump's hyperbole that one can argue is fairly strategic. Lakoff has called this tactic a "trial balloon" (Lakoff, 2017 b). It is worth noting that the tactic does not necessarily - much less exclusively - utilize hyperbole. The latter is just one of the possible means of ascertaining how the public will react to an idea that is being articulated. For instance, in his well-publicized speech on immigration (Trump, 2016 a), Trump lamented the inadequate legislation and enforcement of immigration laws in the country, which he blamed entirely on the Obama administration and his rival, Hillary Clinton, who served as Secretary of State during Obama's first term. As is usually the case with Trump, this was a populist speech, in which he promoted his prospective anti-immigration policies and criticized his predecessor, often unfairly and bluntly. The hyperboles used were intended to depict the immigration problem in America as dire, Obama's government as criminally irresponsible and Clinton as a candidate who was completely incompetent and thus inadequate to deal with an issue of that scale:

(10) And our local police will be so happy that they don't have to be abused by these thugs anymore... and now finally we will turn the tables and law enforcement and our police will be allowed to clear up this dangerous and threatening mess (Trump, 2016 a).

(11) Clinton has also pledged to add a third executive amnesty. And by the way, folks, she will be a disaster for our country, a disaster in so many other ways (Trump, 2016 a).

One could argue that painting an exaggerated picture with regard to the current immigration policies allows Trump to gauge future response to his proposed policies and prepare the public for them. It is therefore safe to maintain that the use of hyperbole by Trump is far more strategic, typologically varied and functionally diverse.

\subsection{Attaching labels}

A characteristic that seems to set Trump apart not only from ordinary politicians but even from many other demagogues is a tendency to categorize and conceptualize certain social groups by labeling them in a way that makes it harder - if not impossible - for other groups in society, i.e. his actual - or potential - voters, to view them favorably. From the early days of his presidential run, Trump gave his main rival Hillary Clinton a nickname, Crooked Hillary, and throughout the entire campaign, he consistently used this designation whenever he spoke about or referred to her, including on Twitter, and by so doing he made sure that the Democratic candidate was firmly associated with crookedness. Almost everyone who was either in opposition to or in competition with Trump had their name modified by an adjective with negative semantics, Lyin'Ted (Ted Cruz), Little Marco (Marco Rubio), Corrupt Kaine (Tim Kaine) and Low-energy Bush (Jeb Bush) being the most salient examples. The Democratic senator Elizabeth Warren, highly critical of him throughout the campaign, was consistently referred to as Pocahontas ${ }^{l}$, which was a jab at her claim that she was of Native American descent. Not only is the fact of being stigmatized a certain way offensive in and of itself, but Trump's constant reference to Warren's self-proclaimed heritage served as a constant reminder of the controversy around her roots that made her look dishonest in the eyes of the public. The result of a repeated use of designations like these is that, since the character flaws, bad judgment, transgressions etc. that the nicknames evoke are constantly foregrounded in the public consciousness, the public are prevented from forgetting, forgiving or otherwise disregarding them. As a consequence, the people thus targeted find it harder to maintain their credibility. More recently, as most mainstream media have sought to hold Trump, the president, accountable for his actions, some of the more outspoken critics among them have also become targets of stigmatization. Impartial coverage

${ }^{1}$ A 17 th century Native American woman who was known for her association with the English colonists 
by the New York Times of Trump, first as candidate and now as president, has led him to refer to this respectable news outlet as the failing NY Times. The effectiveness of this tactic is that the modifying word is not a randomly chosen word with negative semantics, i.e. entirely built on fiction. In the case of the NYTimes, Trump took a fact - a fall in revenue due to diminishing digital advertising - and made it sound like a permanent trend. Yet a singular event does not necessarily point to a trend, all the more so that the falls in revenue have followed recent media industry trends, to which hardly any outlets have been immune. Trump was most probably aware of that, and deliberately singling out one particular outlet for attack was clearly a tactic.

This tactic may well be intuitive on Trump's part, but in fact it appeals to ordinary thought mechanisms and has a significant cognitive effect in the people he is addressing, as was noted above in the paragraph on repetitions. It should be borne in mind that attaching labels to individuals or social groups is believed to be an important step toward vilifying them. Negative labeling helps shape, define and perpetuate their adversarial status. Labeling also facilitates the targeting of such individuals on the basis of group affiliation, subsequently making members of such groups readily identifiable for censure (in the case of the media), disenfranchisement (in the case of immigrants and their families or family members of terrorists and terrorist suspects) but also potential detention and deportation (immigrants).

\section{Implicitness and Presuppositions}

Implicit meaning appears to be a pervasive property of language as not all meaning is immediately manifest in speech or writing, but rather is hidden or assumed. This type of meaning is commonly referred to in linguistic pragmatics and CDA as presuppositions, which are understood as "implicit claims embedded within the explicit meaning of a text or utterance" (Richardson, 2007: 63). As well as presuppositions, the focus of pragmatics are other types of implicit meaning, notably entailments and implicatures, but they will not be considered here. Presuppositions would seem like an effective tool of communicating information, since they operate, so to speak, beneath the surface of texts and enable the author/speaker to convey messages which s/he would not dare articulate openly. Any speech or writing is a combination of differing degrees of explicit representation and implicit meaning. Presuppositions, Fairclough notes, "anchor the new in the old, the unknown in the known, the contentious in the commonsensical" (Fairclough, 1995: 107). It would seem that this latter property of presuppositions to embed contentious information within non-contentious lends itself particularly well to political discourse. Trump, who is adept at intuitively manipulating the message that he is communicating, is known to draw on deeply entrenched assumptions in his speech. One might counterargue here that, as someone who positions himself as a 'straight shooter', i.e. uses explicit, rather than implicit, strategies of conveying information, Trump would hardly need to exert any special effort to embed presupposed meanings. Contrary to this intuitive logic, however, his communicative behavior reveals a great deal of language that embeds and triggers presuppositions. Part of the reason, we believe, is that if something is presumed and not stated directly, it offers the speaker room for maneuver and potential to hedge over whether what the presupposition points to is indeed the intended meaning.

Let us now consider some of the more salient examples of 'beneath-the-surface' assumptions in Trump's speech. The nostalgic slogan on which Donald Trump ran for president - Make America Great Again - draws its meaning from an embedded claim that America used to be great, but is not currently. The phrase also presupposes the possibility of returning the country to the state of greatness which it once enjoyed. An even deeper presupposition is that the person who repeats this appeal is, logically enough, capable of accomplishing what he says. Identical 
presuppositions invoked by the same iterative form are present in extended promises modeled on the original slogan We Will Make America Strong Again; We Will Make America Proud Again; We Will Make America Safe Again. It is noteworthy that, according to basic measures and statistics, the eight years of Obama's presidency had left the country in far better condition than Obama found it. The economy continued to grow, unemployment had declined and the country was not as actively involved in military conflicts around the world as was the case under President Bush. Just because the meaning in these statements is presumed, rather than explicated, it is hard to challenge the speaker over what precisely he means.

Fairclough, in his analysis of assumptions - which are often used interchangeably with the term 'presuppositions' - cites three types of these: existential, propositional, and value assumptions (Fairclough, 2007: 55). Existential assumptions are about what is there in the world; what exists. Propositional ones describe what is or will be done. Finally, evaluative presuppositions are triggered by statements about the desirability or undesirability of what is stated (Fairclough, 2007: 55). It might be informative to consider what presumed meanings can be found in Trump's inaugural address, which we have cited above. At the very beginning of the speech, the newly-sworn-in president declares:

(12) We, the citizens of America, are now joined in a great national effort to rebuild our country and restore its promise for all of our people (Trump, 2017). The proposition about the nation being joined in an effort to rebuild the country embeds an essential existential assumption presenting as a given, as a taken-for-granted fact that the aforesaid effort is there, that it is real. The 'new' information of the proposition matter-of-factly presumes the 'old' information of the ongoing effort. Triggering this assumption is important for Trump as he would like to dissociate himself from the turmoil of his presidential campaign, the contentious character of which is alleged to have left the nation more polarized than ever before. As president, therefore, he sets out to present the unified American nation as given knowledge for the audience.

As was noted above, Trump's inaugural speech draws a picture of the dismal state of the country's economy, its infrastructure, education, immigration policies etc. That effect is triggered, to a large degree, by both existential and propositional assumptions: about the dire state of affairs in the country: (13) This American carnage stops right here and stops right now (Trump, 2017); about the American military having been significantly depleted: (14) For many decades, we've enriched foreign industry at the expense of American industry, subsidized the armies of other countries while allowing for the very sad depletion of our military (Trump, 2017); and about the fact that other countries have been taking advantage of the US potential: (15) We must protect our borders from the ravages of other countries making our products, stealing our companies and destroying our jobs (Trump, 2017), etc. As might be expected, in an inspirational speech like an inaugural address, one would observe multiple instances of value statements, many of which will be triggered by presuppositions. Conventionally, inaugural speeches, because they look into the future, focus on the positive and are designed to inspire optimism and confidence in the newly-sworn administration. In this respect, however, Trump's address stands in sharp relief to how his predecessors addressed the nation on the inauguration day. Many of the value statements in it reflect his personal value system, e.g. the value of winning: (16) America will start winning again, winning like never before); his ideology, e.g. protectionism: (17) Protection will lead to great prosperity and strength; and criticism of his predecessor(s): (18) So to all Americans in every city near and far, small and large, from mountain to mountain, from ocean to ocean, hear these words -- you will never be ignored again (Trump, 2017). Here, one can discern how an ideological or value proposition is effectively embedded within the implicit meaning of the statement. 


\section{Conclusion}

The linguistic data analyzed in the present study has demonstrated many features in Donald Trump's linguistic behavior that can be categorized as idiosyncratic. As an unconventional politician, he displays communicative strategies that differentiate him not only from mainstream politicians and establishment Republicans, but even from many known populists. In the present paper, we have undertaken to address some of the more salient features of his communicative behavior that we believe might have contributed to his eventual win. His effective use of the affective component of communication manifests itself in multiple rhetorical strategies, of which we have singled out his use of repetitions, hyperbole and attaching labels to opponents and individuals or institutions critical of him. Our data suggests that repetitions are essential in making his ideas stick in the minds of the public, and hyperbole can play the role of a 'trial balloon', i.e. help him gauge the reaction of the public to what he might plan to do. Attaching negative labels to opponents ensures that it becomes harder for them to maintain credibility. Finally, in our analysis of presuppositions we have looked at them from the perspective of existential, propositional and value assumptions. Our examination of implicitness reveals that through the use of presumed views, ideological positions and value statements that are embedded in and triggered by his language, Trump has the ability to maintain 'plausible deniability', i.e. he is able to 'test the waters' without having to clearly state his views.

\section{References}

Aristotle. (2012). Rhetoric. Simon \& Brown.

Burke, K. (1974). The rhetoric of Hitler's battle. In: The philosophy of literary form: Studies in symbolic action. University of California Press.

Claridge, C. (2014). Hyperbole in English: A corpus-based study of exaggeration. Cambridge University Press.

Dijk, T. van (2001). Multidisciplinary CDA: A plea for diversity. In: R. Wodak and M. Meyer, eds. Methods of critical discourse analysis. London: Sage.

Fairclough, N. (1995). Media discourse. London: Hodder Arnold.

Fairclough, N. (2003). Analysing discourse: Textual analysis for social research. Routledge.

Fillmore, Ch. J. (1982). Frame semantics. In: Linguistics in the morning calm. Seoul: Hanshin Publishing Company, Linguistics Society of Korea.

Healy, P., and Haberman, M. (2015). 95,000 words, many of them ominous, from Donald Trump's Tongue. The New York Times. [Accessed 23 February 2016]. Available at: https://www.nytimes.com/2015/12/05/us/politics/95000-words-many-of-them-ominous-fromdonald-trumps-tongue.html?_r=0

Hyland, K. (2005). Metadiscourse: Exploring interaction in writing. Bloomsbury Publishing.

Lakoff, G. (2008). The political mind: Why you can't understand 21 st-century American politics with an 18th-century brain. New York: Viking Penguin.

Lakoff, G. (2016 a). A minority president: Why the polls failed and what the majority can do. [Accessed 10 December 2016]. Available at: https://georgelakoff.com/2016/11/22/a-minoritypresident-why-the-polls-failed-and-what-the-majority-can-do/\#more-5389

Lakoff, G. (2016 b). How to help Trump. [Accessed 23 February 2017]. Available at: https://georgelakoff.com/2016/12/15/how-to-help-trump/

Lakoff, G. (2017 a). Understanding Trump's use of language. The Huffington Post. August 25. [Accessed 2 September 2017]. Available at: http://www.huffingtonpost.com/george-lakoffl understanding-trumps-use-_b_11675280.html 
Lakoff, G. (2017 b). Trump's Twitter distraction. [Accessed 8 March 2017]. Available at: https://georgelakoff.com/2017/03/07/trumps-twitter-distraction/

Lakoff, G., and Johnson, M. (1999). Philosophy in the flesh: The embodied mind and its challenge to Western thought. New York: Basic Books.

Leeuwen, Th. Van (2008). Discourse and practice: New tools for critical discourse analysis. New York: Oxford University Press.

Libit D. (2016). Transcribers' agony: Frustrated not by what Trump says but how he says it [Accessed 2 September 2017] Available at: http://www.cnbc.com/2016/08/15/transcribers-agony-frustrated-not-by-what-trump-says-but-how-he-says-it.html

Mangan, D. (2017). Donald Trump says Obamacare repeal and replacement to come with confirmation of Price as HHS chief. [Accessed 20 January 2017] Available at: https://www.cnbc.com/2017/01/11/donald-trump-addresses-obamacare-repeal-and-replacement-at-press-conference-in-new-york.html

Nichols, Ch. (2016). Donald Trump brings troublesome relationship with the truth to California. Politifact. [Accessed 2 February 2017]. Available at: http://www.politifact.com/california/ article/2016/apr/26/donald-trump-candidate-profile/

Nossel, S. (2018). Trump's attacks on the press are illegal. We're suing. [Accessed 23 February 2019]. Available at: https://www.politico.com/magazine/story/2018/10/16/trumps-attacks-onthe-press-are-illegal-were-suing-221312

Paradis, C. (2000). Reinforcing adjectives: A cognitive semantic perspective on grammaticalization. In: R. Bermúdez-Otero, D. Denison, R. Hogg, and C. B. McCully, eds. Generative Theory and Corpus Studies, vol. Topics in English linguistics, no. 31, Mouton de Gruyter.

Richardson, J.E. (2007). Analysing newspapers: An approach from critical discourse analysis. Palgrave Macmillan.

Shamsian, J. (2015). Donald Trump opens the debate by bragging about 'making billions of dollars'. [Accessed 2 February 2017]. Available at:

https://www.businessinsider.com/donald-trump-opens-the-debate-by-bragging-about-makingbillions-of-dollars-2015-9

Stanley, B. (2008). The thin ideology of populism. In: Journal of Political Ideologies, vol. 13, no. 1 , pp. $95-110$.

Trump, D. (2015). Here's Donald Trump's presidential announcement speech. [Accessed 2 February 2017]. Available at:

https://time.com/3923128/donald-trump-announcement-speech/

Trump, D. (2016 a). Transcript of Donald Trump's Immigration speech. 2016 a. The New York Times. [Accessed 2 February 2017]. Available at: https://www.nytimes.com/2016/09/02/us/politics/transcript-trump-immigration-speech.html

Trump, D. (2016 b). Full Text: Donald Trump's 2016 Republican National Convention Speech. [Accessed 2 February 2017]. Available at:

https://abcnews.go.com/Politics/full-text-donald-trumps-2016-republican-national-convention/story?id $=40786529$

Trump, D. (2016 c). Trump: The art of the deal. Random House.

Trump, D. (2017). The Inaugural address. [Accessed 13 October 2018]. Available at: https://www.whitehouse.gov/briefings-statements/the-inaugural-address/

2016 presidential candidates on the Trans-Pacific Partnership trade deal. In: Ballotpedia. [Accessed 2 February 2017]. Available at:

https://ballotpedia.org/2016_presidential_candidates_on_the_Trans-Pacific_Partnership_ trade_deal 